\title{
Reappearance and seasonality of Phyllorhiza punctata von Lendenfeld (Cnidaria, Scyphozoa, Rhizostomeae) medusae in southern Brazil ${ }^{1}$
}

\author{
Maria A. Haddad ${ }^{2} \&$ Miodeli Nogueira Júnior ${ }^{2}$ \\ 1 Contribuição número 1649 do Departamento de Zoologia, Universidade Federal do Paraná. \\ ${ }^{2}$ Departamento de Zoologia, Universidade Federal do Paraná. Caixa Postal 19020, 81531-980 Curitiba, Paraná, Brasil. \\ E-mail: mahaddad@ufpr.br; miodeli@gmail.com
}

\begin{abstract}
The scyphozoan Phyllorhiza punctata von Lendenfeld, 1884 (Mastigiidae), known only from IndoPacific waters prior to the 1950s, is today found far from its original distribution, probably due to human activities. First seen in 1955 in Brazilian waters, medusae were found in southern and southeastern coasts, disappearing (at least as a medusa) in the early 1960's. Another population was found in the late 1990's, in the state of Bahia, and again in late 2001, many sightings were reported along the coasts of Paraná and Santa Catarina $\left(25^{\circ} 20^{\prime} \mathrm{S}, 48^{\circ} 12^{\prime} \mathrm{W}\right.$ to $\left.27^{\circ} 26^{\prime} \mathrm{S}, 48^{\circ} 22^{\prime} \mathrm{W}\right)$. A large summer bloom, followed by decline and disappearance in winter and spring, occurs every year since then. The reasons for this recent mass occurrence are unknown. Despite few scattered records of the species in Brazil, it is probably widespread, occurring from the coast of Ceará $\left(3^{\circ} 43^{\prime} \mathrm{S}, 38^{\circ} 28^{\prime} \mathrm{W}\right)$, in the northeast, to Santa Catarina, in the south.
\end{abstract}

KEY WORDS. Introduced species; jellyfish; population dynamics; seasonal.

RESUMO. Reaparecimento e sazonalidade da medusa Phyllorhiza punctata von Lendenfeld (Cnidaria, Scyphozoa, Rhizostomeae) no sul do Brasil. A cifomedusa Phyllorhiza punctata von Lendenfeld, 1884 (Mastigiidae), conhecida somente de águas do Indo-Pacífico até a década de 1950, é encontrada atualmente em diversos locais longe de sua distribuição original, provavelmente devido a atividades humanas. No Brasil, foi encontrada primeiramente em 1955 nas costas sul e sudeste, de onde desapareceu, ao menos no estágio de medusa, no início dos anos 1960. Uma outra população de medusas apareceu na década de 1990 no litoral do Estado da Bahia e, desde o final de 2001, reapareceram no litoral dos Estados do Paraná e Santa Catarina $\left(25^{\circ} 20^{\prime} \mathrm{S}, 48^{\circ} 12^{\prime} \mathrm{W}\right.$ a $\left.27^{\circ} 26^{\prime} \mathrm{S}, 48^{\circ} 22^{\prime} \mathrm{W}\right)$, onde têm ocorrido em grande abundância durante os meses de verão. Durante o outono, segue um declínio da população, até seu desaparecimento no inverno. As razões desse recente aparecimento da espécie no Brasil são desconhecidas, entretanto, apesar dos poucos e esparsos registros, sua distribuição provavelmente ampliou-se por toda a costa, ocorrendo desde o Ceará ( $\left.3^{\circ} 43^{\prime} \mathrm{S}, 38^{\circ} 28^{\prime} \mathrm{W}\right)$, na região nordeste, até Santa Catarina, no sul do país.

PALAVRAS-CHAVE. Água-viva; dinâmica populacional; espécie exótica; sazonalidade.

Cnidarians are among many marine groups whose distributions are changing due to human activities, with many species being transported in ballast waters or attached to the hulls of ships (ARAI 1997). It is usually difficult to establish whether the species is indeed invasive or cryptic, and determine when it arrived (Rосна 2002). These problems are especially difficult in poorly studied regions, such as the Brazilian coast, and for poorly studied taxonomic groups as cnidarians.

The spotted jellyfish Phyllorhiza punctata von Lendenfeld, 1884 (Scyphozoa, Rhizostomeae, Mastigiidae) is a large and colorful scyphomedusa, reaching up to $60 \mathrm{~cm}$ in diameter. It was originally described from Port Jackson, eastern Australia with an Indo-Pacific distribution (Mayer 1910, Rippingale \& Kelly
1995). Since the 1950 's, reports of $P$. punctata interpreted as invasions have been recorded around the world (review and map in Graham et al. 2003). Among invasive marine species, it has a relatively well-documented history of invading tropical and subtropical environments, although there is no direct evidence of translocation routes, source populations, or mechanisms by which translocation has occurred (Bolton \& Graham 2004). The last massive invasion of $P$. punctata described in literature occurred across the northern Gulf of Mexico, when an estimated 10 million medusae occupied the Mississipi Sound region (USA), in the summer of 2000, spreading into the coastal and lagoon waters of east Florida coast in 2001 (GraHAm et al. 2003).

Revista Brasileira de Zoologia 23 (3): 824-831, setembro 2006 
Current theory suggests that the species was introduced to Atlantic basin through the Panama Canal (Graham et al. 2003, Bolton \& Graham 2004), probably by scyphistomae attached to ship hulls (LARSON \& ARNESON 1990). However, scyphistoma have never been found attached to ships (ARAI 1997: 202). On the other hand, transport by ballast-water could explain several invasions of the species through the world, as suggested by CARLTON \& GELLER (1993) about the invasion of $P$. punctata to Californian waters.

The strong and characteristic coloration, together with the big size attained and the habit of staying in the upper layers of the water column, due to the presence of zooxanthelae, facilitate sightings and population monitoring of this species. Nevertheless, it is poorly studied, and only three researches on its life cycle and seasonal occurrence were found. GARCIA (1990) studied medusae in Laguna Joyuda, a tropical estuary in Puerto Rico, providing the basic characterization of the growth dynamics and production of the species. In the Swan-Canning estuary of western Australia, Rippingale \& Kelly (1995) related the seasonal cycle of $P$. punctata to salinity, temperature and photoperiod. Graham et al. (2003) in a rapid sampling program in 2000 obtained ecological information on a large population that invaded the northern Gulf of Mexico (USA).

In Brazilian waters, this jellyfish was first seen in the 1950's when medusae were abundant along the southeastern and southern coasts (Moreira 1961, described as Mastigias scintillae) and this is the earliest published report of this medusa in the Atlantic basin. The population, at least the medusae stage, disappeared a few years later. More recently, an apparent well established population of $P$. punctata was found in the northeastern state of Bahia (Silveira \& Cornelius 2000) and in late 2001, the species appeared again in the coast of southeast (São Sebastião Channel, São Paulo state) (F.L. da Silveira \& A.C. Morandini personal communication) and south (Paraná and Santa Catarina states) regions.

Here we present some aspects of the biometry and development of the medusa stage of $P$. punctata, and we discuss briefly some possible mechanisms of its massive reappearance in southern Brazilian waters, since 2001. This paper is also the first one to present data on a scyphozoan seasonal occurrence and growth along the Brazilian coast.

\section{MATERIAL AND METHODS}

Collections and observations were conducted on the coast of the states of Paraná and Santa Catarina, in southern Brazil $\left(25^{\circ} 20^{\prime} \mathrm{S}, 48^{\circ} 12^{\prime} \mathrm{W}\right.$ to $\left.26^{\circ} 08^{\prime} \mathrm{S}, 48^{\circ} 38^{\prime} \mathrm{W}\right)$. Despite the small coastline, the region includes three large estuarine regions, Paranaguá, Guaratuba and São Francisco Bays.

The oceanographic characteristics of this region are marked by strong seasonality on the patterns of water masses, with the temperature showing high amplitude according to the season (CASTRO-FILHO et al. 1987). It is considered as coastal subtropical (BoLtovsкoy et al. 1999) or warm temperate (GIBBONS 1997). The climate is classified as Cfa following Koeppen, with the coldest month between 3 to $18^{\circ} \mathrm{C}$ (Bigarella 1978).
Observations and collections were made as follow: 1) from a boat, individuals were caught with a $1 \mathrm{~mm}$ mesh hand net in Paranaguá Bay, between March and May 2002. Umbrelar diameter and length of the largest oral arm without terminal appendages were measured, after which they were returned to the water (SoвоLewsкi et al. 2004); 2) monthly observations, from boats and docks, along the beaches of Pontal do Paraná and Guaratuba (Paraná), and sporadically of Barra do Sul (Santa Catarina), from December 2002 to March 2005; in these occasions, the size classes of living medusae were visually estimated; 3) stranded medusae found by beach searches on foot, at the same beaches and frequency as cited above in the second item, between January 2003 and March 2005. The umbrelar diameter of these stranded individuals was measured. 4) live medusae were collected monthly, in the shallow platform (8 to 12 m) of Guaratuba, from February 2003 to December 2004, with otter trawls $2 \mathrm{~cm}$ mesh size. These samples were taken to the laboratory and preserved in $4 \%$ formaldehyde solution in seawater for later anatomical study. Umbrelar diameter and wet weight were recorded prior to preservation.

Water surface temperature was taken during the boat samples with a calibrated thermometer and varied between 12 $29.5^{\circ} \mathrm{C}$ during the studied period.

The diagnose of the species follows Mayer 1910, Kramp 1961, Moreira 1961 (as Mastigias scintillae), Cutress 1973, Mianzan \& Cornelius 1999, Silveira \& Cornelius 2000, Bolton \& Graham 2004). Voucher specimens were deposited in the Museu de Zoologia da Universidade de São Paulo (MZUSP-899, four small exemplars).

\section{RESULTS}

A total of 340 individuals of Phyllorhiza punctata von Lendenfeld, 1884 were identified based in its diagnostic characters: "eight radial canals (four each, perradial and interradial) arising from the cruciform central stomach and extending to the eight marginal sense-clubs. A wide ring-canal connects the eight radial-canals. On its outer side the ring-canal gives rise to fine-meshed network of vessels, that fuses with the radial-canals, extending to the lappet zone. From its inner sided the ring-canal a similar network of vessels originates that connects with the central stomach and the four interradial canals. Oral arms are J-shaped and there are three window-like openings in the lateral membrane. Living specimens are brown, with conspicuous white spots" (Fig. 1).

Bell diameter varied from 2 to $470 \mathrm{~mm}$. Oral arms length varied from 10 to $320 \mathrm{~mm}$. The relationship between both variables followed a linear pattern, with oral arms tending to be nearly $66 \%$ of the bell diameter (Fig. 2). The relationship between the bell diameter and oral arms length keeps constant in the different size classes. The wet weight ranged from 0.26 to $3882.2 \mathrm{~g}$. The relative growth of the species is shown in the figure 3 , from where can be seen that the weight had a negative alometry in relation to the diameter. 


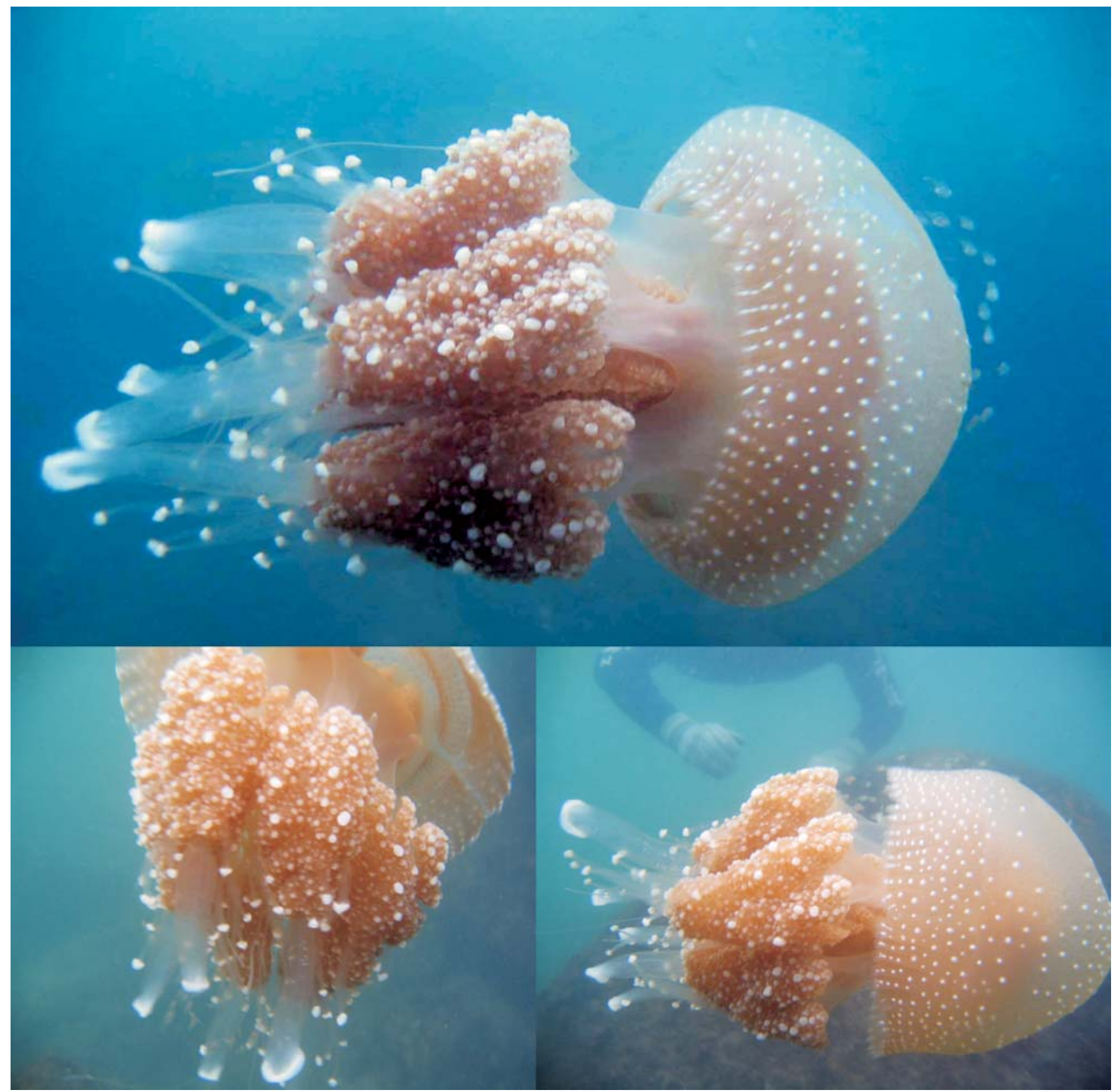

Figure 1. Live Phyllorhiza punctata photographed in situ. Photos by Leopoldo Gerhardinger.

\section{The seasonal cycle}

In southern Brazil, the scyphomedusae $P$. punctata reappearance was first noted in late 2001. During the four years surveyed (2002-2005), this medusae showed an marked annual cycle in the studied area, with a large summer bloom followed by a decline and disappearance through late autumn. Small medusae $(<20 \mathrm{~mm})$ began to appear in January or February, and were usually found until March. In January 2004, 10 very small medusae $(2-5 \mathrm{~mm})$ appeared in a plankton sample made by other researchers in the same area. They grew very quickly during six to eight weeks through March and April, when they averaged $30-35 \mathrm{~cm}$ in diameter (Fig. 4). Some smaller individuals were collected also in May 2002 and 2003, but nor young neither adult ones were seen during winter. Due to the more sporadic sampling procedures realized in Barra do Sul (Santa Catarina), these data were not included in the analysis, al-

Revista Brasileira de Zoologia 23 (3): 824-831, setembro 2006 

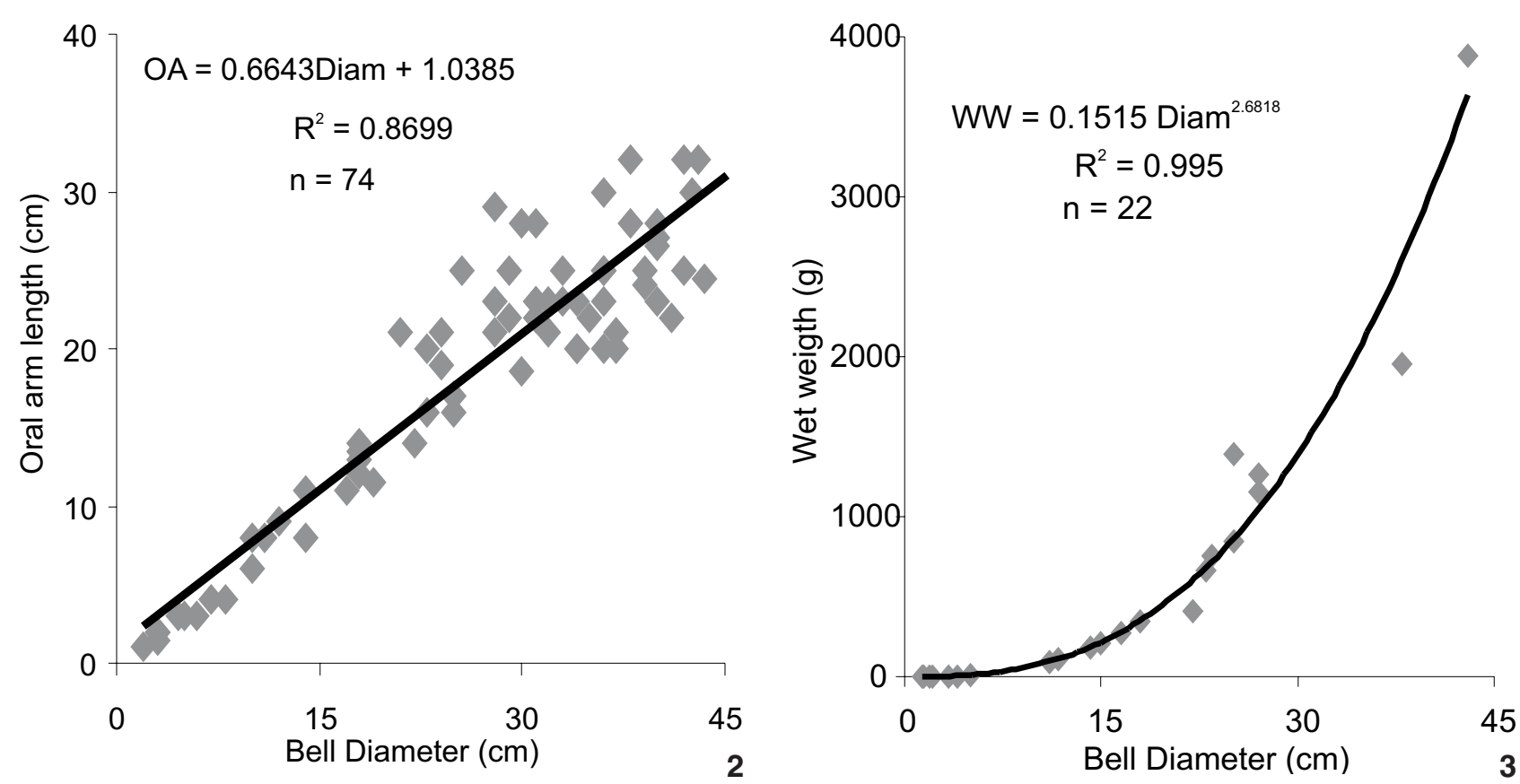

Figures 2-3. Morphometric patterns of P. punctata population from southern Brazil. 1. Relationship between the bell diameter and length of the biggest oral arm, 2. Relationship between the bell diameter and wet weight (Diam) Bell biameter, (OA) oral arm, (WW) wet weight.

though, the population seems to follow a very similar pattern of both occurrence and size distribution.

\section{DISCUSSION}

Specimens were strongly pigmented with symbiotic zooxanthelae, as in almost all populations described (MOREIRA 1961, Cutress 1973, Galil et al. 1990, Garcia 1990, Larson \& Arneson 1990, Rippingale \& Kelly 1995, Silveira \& Cornelius 2000; but see Graham et al. 2003, Bolton \& Graham 2004).

We presented a basic characterization on biometric patterns of $P$. punctata studied population, what we hope will be useful for future comparisons with other populations, as well for standing stock estimates from visual census, since these data have not thus far been available in the literature. The $b$ coefficient of the size-wet weight relationship falls within the range reported to other scyphozoan species (Weisse \& Gomolu 2000, Buecher et al. 2001).

\section{The seasonal cycle}

The seasonal pattern of abundance and rapid growth rates of $P$. punctata observed in the studied area were similar for other populations of the species. Small $(<2 \mathrm{~cm}$ diameter $)$ medusae and ephyrae of a $P$. punctata population appeared in early summer, in the Swan-Canning estuary of Western Australia (Rippingale \& Kelly 1995). After six weeks, they reached $15 \mathrm{~cm}$ in bell diameter, were able to reproduce sexually and already produced planulae. Six to eight weeks was also the growth pe- riod of the species observed in this study. The large bleached population that invaded the northern Gulf of Mexico (USA), in May 2000, had a bell diameter 50\% larger than the average of $32 \mathrm{~cm}$ in early July, and around 12 August and through early autumn they began to die (Graham et al. 2003). Summer maximum abundance and rapid growth of the species also occurred in Laguna Joyuda, Puerto Rico (GARCIA 1990). Unlike the population of the studied area, that of Puerto Rico did not show seasonality, with medusae of all sizes sampled at any time, except in the winter months of January and February. This difference is possibly due to higher, year-long water temperatures ( 24 to $32^{\circ} \mathrm{C}$ ), typical of tropical coastal lagoons with shallow waters (average depth of $1.5 \mathrm{~m}$ ). Moreira (1961) commented that the medusae "become conspicuous and very abundant during summer months with young and mature individual occurring together". In this study, individuals of all sizes were also observed from January to March, indicated by the high range of the bars in the figure 4 , suggesting a continuous period of ephyrae release, which is coincident with a rise in the water temperature and the photoperiod. In the laboratory cultures of RipPingale \& Kelly (1995) the production of ephyrae did not occur regularly, however during November 1993 and 1994 (mid Spring) they observed a simultaneous release of ephyrae. A rise in water temperature from $\sim 16$ to $\sim 24^{\circ} \mathrm{C}$ and a gradual change in photoperiod occurred prior to this observation.

Natural populations of $P$. punctata scyphistomae were never localized, despite the repeated efforts of RippingaLe \& KeLLY 

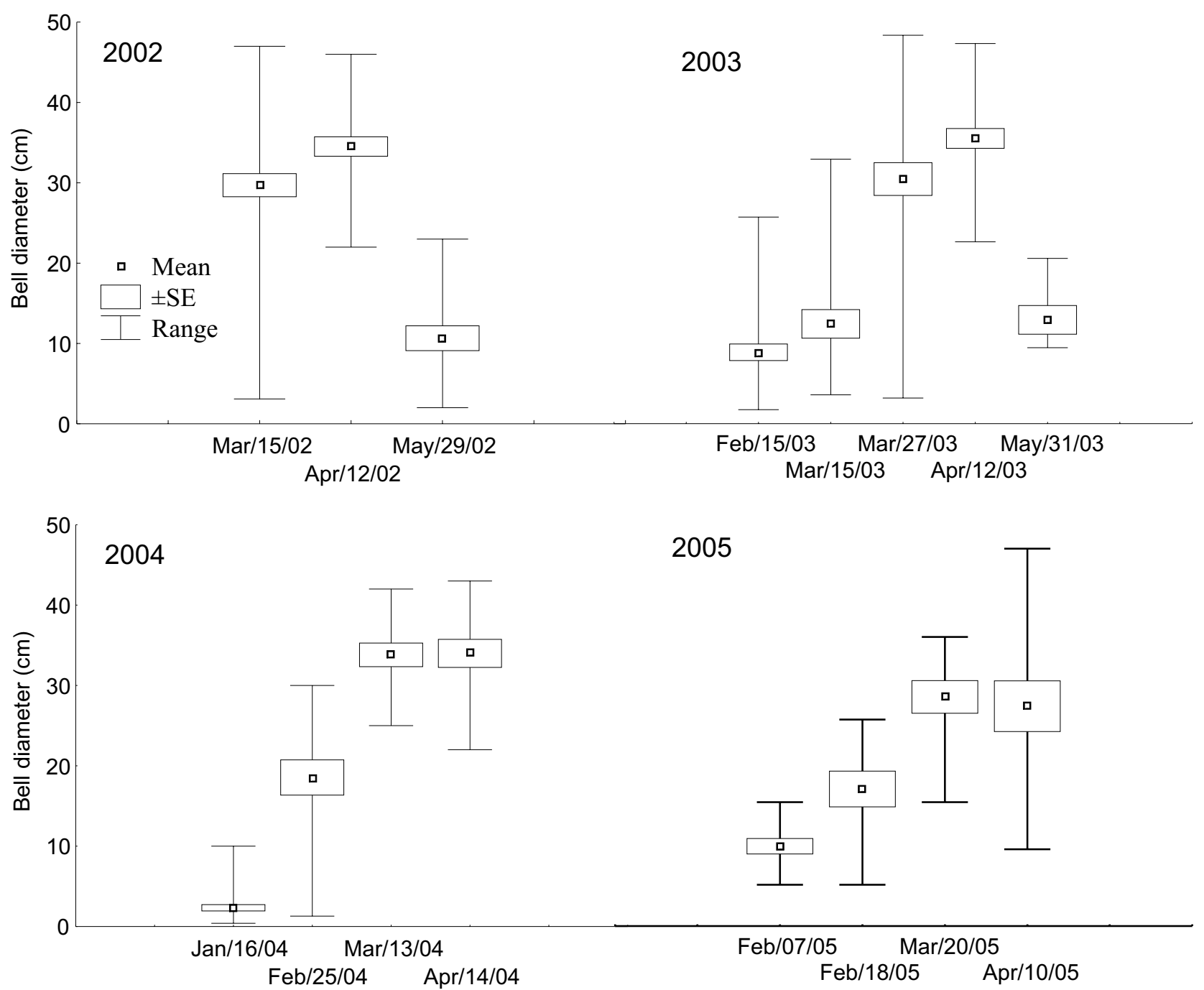

Figure 4. Mean and range of bell diameter of $P$. punctata during the four years surveyed: 2002 - data from Paranaguá Bay: March $\mathrm{n}=31$, April $n=29$, May $n=16.2003$ - mixed data from Guaratuba and Pontal do Sul: February $n=30$, March/15 $n=25$, March/27 $n=31$, April $n=29$, May $n=22.2004$ - mixed data from Guaratuba and Pontal do Sul: January $n=26$, February $n=18$, March $n=16$, April $n=15.2005$ - mixed data from Guaratuba and Pontal do Sul: February/07 $n=19$, February/18 $n=14$, March $n=15, A p r i l n=15$ ).

(1995) to locate them. These authors hypothesize, from laboratory experiments, that the polyps probably are located inside the estuaries and survive the winter, in low salinity $(<10)$ and low water temperatures $\left(<20^{\circ} \mathrm{C}\right)$ of the upper $5 \mathrm{~m}$ of the water column. These results may explain the very similar seasonal cycle observed in the population studied here, in the southern Brazilian coast, where the temperature variations are similar with that of south Australia. Also, large estuaries nearby could shelter the population of scyphistoma or other resting stages that probably overwinter, since medusae were absent during winter-spring months.

The very small medusae obtained in early summer also point to the presence of scyphistomae populations in Paraná and Santa Catarina regions, with the whole life cycle of the species occurring in the area. In April 2001, and in January and February 2002, ephyrae have also been collected in Cananéia, São Paulo (Tronolone et al. 2002).

Smaller individuals caught in late May probably were senescent. Autumn senescence was reported in $P$. punctata in Laguna Joyuda. Starvation, parasitism, predation and genetic determination have been proposed as potential causes for the population decline of scyphomedusae (GARCIA 1990, ARAI 1997). In some specimens sexed males and females were observed. This is different of other populations that seemed to be com-

Revista Brasileira de Zoologia 23 (3): 824-831, setembro 2006 
posed exclusively of males (Moreira 1961, Graham et al. 2003).

\section{The distribution of $P$. punctata in Brazil}

The first Brazilian population recorded was briefly very abundant on the coast of Rio de Janeiro, São Paulo and Paraná, in the 1950's (Moreira 1961), but disappeared a few years later at least at the medusae stage. Marine biologists and local fishermen working on the coast of Paraná since the early 1960's never encountered this large and conspicuous species (J. de Loyola e Silva personal communication). More recently, another population of $P$. punctata was reported more northern, at Todos os Santos Bay, in the state of Bahia, apparently there since 1991 (Silveira \& Cornelius 2000). Further north, medusae have been seen since 2003 in Fortaleza, state of Ceará (M.O. Soares personal communication) (Fig. 5).

In southern and southeastern Brazil, $P$. punctata medusae reappeared abundantly in late 2001 . They have been seen from São Sebastião $\left(23^{\circ} 50^{\prime}\right.$ S, $\left.45^{\circ} 26^{\prime} \mathrm{W}\right)$, in São Paulo state (F.L. da Silveira \& A.C. Morandini, personal communication), and as far south as Florianópolis $\left(27^{\circ} 26^{\prime} \mathrm{S}, 48^{\circ} 22^{\prime} \mathrm{W}\right)$, in Santa Catarina state. Aside from the large conspicuous medusae seen by local people, several small ( $<20 \mathrm{~mm}$ in diameter) specimens collected indicate that the species became established in the area.

It is not known whether this recent appearance of $P$. punctata in southern Brazil is the result of a new regional or international invasion, a natural range expansion of the Bahia population to the south, or only a mass occurrence of a possible cryptic population that has been maintained. A new introduction is possible due to the great ship traffic in the harbors of Santos and Paranaguá. Introduction does not guarantee survival for a species in a new environment. To maintain populations, organisms must be able to feed and reproduce. Endosymbiotic zooxanthelae present in $P$. punctata may play an important role in the nutrition of this species (GARCIA \& DURBIN 1993) and surely may facilitate the establishment of this medusa in new places. By the other hand, some scyphozoan species may have huge blooms interposed by very long periods with inactive polyps (e.g. Goy et al. 1989), depending on the conditions of the environment. Scyphistoma of $P$. punctata lived longer than 12 months (RIPPINGALE \& Kelly 1995), so persistent populations of this or other resting stages could have been cryptic without, or with a very low and undetectable production of medusae. Although details of seawater temperatures in the studied area are unavailable, abnormally hot whether could had facilitate local adaptation and mass occurrence of this tropical jellyfish during the past four years.

These new occurrences in southern and in far northeastern Brazil might suggest that the distribution of the species along Brazilian coast is expanding, with populations spreading along the entire Brazilian coast (Fig. 5). The hypothetic route could be tested with comparative morphological studies, as performed by Bolton \& GRAHAM (2004) for other populations, or with molecular analysis (e.g. isoenzimes).

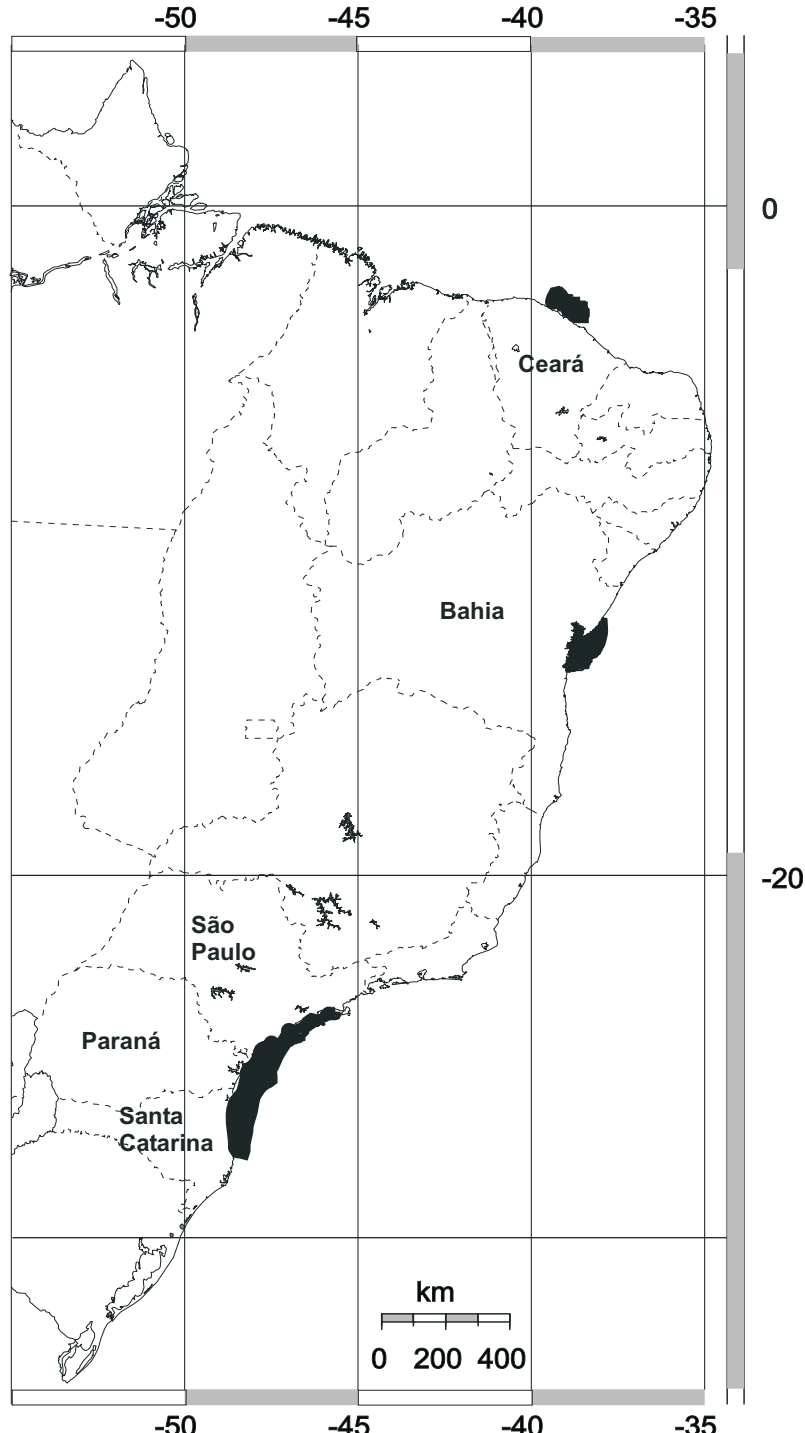

Figure 5. Map showing recent known distribution of $P$. punctata along Brazilian coast.

\section{FINAL CONSIDERATIONS}

The species causes a strong negative influence on shrimp fisheries in the Gulf of Mexico clogging and bursting the nets, with 10 millions of dollars of economic losses (GraHAm et al. 2003). The south Brazilian population have not been abundantly caught by shrimp fisheries, and are not clogging nets here, since the species occurs more abundantly near the surface. An indirect impact by predation of zooplankton has also been related (Graham et al. 2003) and is an important aspect to be clarified in future studies of this population.

Despite few scattered records of $P$. punctata in Brazil, it is probably occurring along the entire coast, from Ceará $\left(3^{\circ} 43^{\prime} \mathrm{S}\right.$, 
$\left.38^{\circ} 28^{\prime} \mathrm{W}\right)$ to Florianópolis $\left(27^{\circ} 26^{\prime} \mathrm{S}, 48^{\circ} 22^{\prime} \mathrm{W}\right)$. It is not possible to determine the cause of this recent bloom occurrence of $P$. punctata medusae in Southern Brazil, but apparently the population is well established, with young and adult medusae being abundantly observed during the summer since the past four years. Only continuous monitoring of the population, with observations of all stages of the life cycle, will help in understanding the factors that lead to this recent mass occurrence of $P$. punctata and evaluate its impact on other populations in the studied area.

\section{ACKNOWLEDGEMENTS}

To Henry L. Spach and Mariana Sobolewski for the 2002 data; André X. Lima, André L. Campos, Fernando C. Straube, Luís H. Condrati, Priscila A. Moreira, and André C. Morandini. Leopoldo Gerhardinger made the photos. CAPES provided scholarship research for the second author.

\section{REFERENCES}

AraI, M.N. 1997. A functional Biology of Scyphozoa. London, Chapman \& Hall, 316p.

Bigarella, J.J. 1978. A Serra do Mar e a Porção Oriental do Estado do Paraná. Curitiba, Secretaria de Planejamento do Estado do Paraná, 248p.

Bolton, T.F. \& W.M. Graham. 2004. Morphological variation among populations of an invasive jellyfish. Marine Ecology Progress Series, Oldendorf, 278: 125-139.

Boltovskoy, D.; M.J. Gibbons; L. Hutchings \& D. Binet. 1999. General biological features of the South Atlantic, p. 1-42. In: D. Boltovsкoy (Ed.). South Atlantic Zooplankton. Leiden, SPB Academic Publishings, 1500p.

Buecher, E.; C. Sparks; A. Brierley; H. Boyer \& M.J. Gibbons. 2001. Biometry and size distribution of Chrysaora hysoscella (Cnidaria, Scyphozoa) and Aequorea aequorea (Cnidaria, Hydrozoa) off Namibia with notes on their parasite Hyperia medusarum. Journal of Plankton Research, Oxford, 23 (10): 1073-1080.

Castro-Filho, B.M.; L.B. Miranda \& Y. Miyao. 1987. Condições hidrográficas na plataforma continental ao largo de Ubatuba; variações sazonais e em média escala. Boletim do Instituto Oceanográfico da Universidade de São Paulo, São Paulo, 35 (2): 135-151.

Carlton, J.T. \& J.B. Geller. 1993. Ecological Roulette: The Global Transport of Nonindigenous Marine Organisms. Science, Stanford, 261: 78-82.

Cutress, C.E. 1973. Phyllorhiza punctata in the Tropical Atlantic. Associations of Island Marine Laboratories of the Caribbean, Cumaná, 9: 14.

Galil, B.S.; E. Spanier \& W.W. Ferguson 1990. The Scyphomedusae of the Mediterranean coast of Israel, including two Lessepsian migrants new to the Mediterranean. Zoolgischë Mededelingen, Leiden, 64 (7): 95-105.

GarCIA, J.R. 1990. Populations dynamics and productions of
Phyllorhiza punctata (Cnidaria: Scyphozoa) in Laguna Joyuda, Puerto Rico. Marine Ecology Progress Series, Oldendorf, 64: 243-251.

GarCia, J.R. \& E. Durbin. 1993. Zooplanktivorous predation by large scyphomedusae Phyllorhiza punctata (Cnidaria: Scyphozoa) in Laguna Joyuda. Journal of Experimental Marine Biology and Ecology, Amsterdam, 173: 71-93.

Gibions, M.J. 1997. Pelagic biogeography of the South Atlantic Ocean. Marine Biology, Berlim, 129: 757-758.

Goy, J.; P. Morand \& M. Etienne. 1989. Long-term fluctuations of Pelagia noctiluca (Cnidaria, Scyphomedua) in the western Mediterranean Sea. Prediction by climatic variables. DeepSea Research, Woods Hole, 36 (2): 269-279.

Graham, W.M.; D.L. Martin; D.L. Felder; V.L. Asper \& H.M. Perry. 2003. Ecological and economical implications of a tropical jellyfish invader in the Gulf of Mexico. Biological Invasions, Leiden, 5: 53-69.

KRAMP, P.L.1961. Synopsis of the Medusae of the World. Journal of Marine Biology Associated of United Kingdom, London, 40: 1-469.

Larson, R.J. \& A.C. Arneson. 1990. Two medusae new to the coast of California: Carybdea marsupialis (Linnaeus, 1758), a cubomedusa and Phyllorhiza punctata von Lendenfeld, 1884 a rhizostome scyphomedusa. Bulletin of the Southern California Academy of Sciences, Los Angeles, 89 (3): 130136.

Mayer, A.G. 1910. The medusae of the world. The Scyphomedusae. Washington, Carnegie Institution, vol. III, p. 499$735 p$.

Mianzan, H. \& P.F.S. Cornelius. 1999. Scyphomedusae and Cubomedusae, p. 513-559. In: D. Boltovskoy (Ed). South Atlantic Zooplankton. Leiden, SPB Academic Publishing, 1500p.

Moreira, M.G.B.S. 1961. Sobre Mastigias scintillae sp. nov. (Scyphomedusae, Rhizostomeae) das costas do Brasil. Boletim do Instituto Oceanográfico da Universidade de São Paulo, São Paulo, 11 (2): 5-30.

Rippingale, R.J. \& S. Kelly. 1995. Reproduction of Phyllorhiza punctata (Cnidaria: Rhizostomeae) in a Seasonally Fluctuating Salinity Regime in Western Australia. Marine Freshwater Research, Victoria, 46: 1145-1151.

RochA, R.M. 2002. Bostricobranchus digonas Abbott (Ascidiaceae, Mogulidae) in Paranaguá Bay, Paraná, Brazil. A case of recent invasion? Revista Brasileira de Zoologia, Curitiba, 19 (1): 157-161.

Silveira, F.L. \& P.F.S. Cornelius, 2000. Novas Observações Sobre Medusas (Cnidaria, Scyphozoa, Rhizostomeae) no nordeste e no sul do Brasil. Acta Biologica Leopoldensia, São Leopoldo, 22 (1): 9-18.

Sobolewski, M.; K.B. Rebuli; M.A. Haddad \& H.L Spach. 2004. Ocorrência da associação entre Phylorhiza punctata von Lendenfeld, 1884 (Cnidaria: Scyphozoa) e peixes na Baía de Paranaguá, estado do Paraná. Arquivos de Ciências do Mar, Fortaleza, 37: 29-34. 
Tronolone, V.B.; A.C. Morandini \& A.E. Migotto. 2002. On the occurrence of scyphozoan ephyrae (Cnidaria, Scyphozoa, Semaeostomeae and Rhizostomeae) in the southeastern Brazilian coast. Biota Neotropica, Campinas, 2 (2): 1-18.
Weisse, T. \& M-T. Gomoiu. 2000. Biomass and size structure of the scyphomedusa Aurelia aurita in the northwestern Black Sea during spring and summer. Journal of Plankton Research, Oxford, 22 (2): 223-239.

Received in 24.VIII.2005; accepted in 27.VIII.2006. 